ARCHIWA - KanCELARIE - ZBIORY

NR $5(7) / 2014$

\title{
Komentarz do listu Roberta Arasimowicza
}

http://dx.doi.org/10.12775/AKZ.2014.006

Nadesłany do redakcji poparty nie tylko refleksją, ale też doświadczeniem autora, emocjonalny, subiektywny list jest jednym z niewielu, jeżeli nie jedynym, publikowanym na łamach pism branżowych głosem w dyskusji dotyczącej zasadności prac publicznych podejmowanych przez archiwa. Jego autor jest użytkownikiem archiwów, ale też czynnym zawodowo archiwistą. Ponadto, co daje się wyczuć w tekście, należy do tej części klientów archiwów, którzy dostrzegają i doceniają misję archiwów i znaczenie zgromadzonych w nich archiwaliów, a także potencjał tych placówek w zakresie ról, jakie mogą odgrywać we współczesnym społeczeństwie z jednej strony, z drugiej chciałby, aby ten potencjał był znany i dostępny dla wszystkich, nie tylko użytkowników zainteresowanych skorzystaniem z zasobu, ale też osób, które dotychczas nie poznały archiwum.

Prace publiczne archiwów, w zakresie których na obecnym etapie rozwoju archiwów mieszczą się działania informacyjne, edukacyjne i promocyjne, są realizacją założeń zasady publiczności, w myśl których każdy człowiek może korzystać na równych zasadach $\mathrm{z}$ archiwów $\mathrm{z}$ jakiegokolwiek powodu, natomiast archiwum ma obowiązek uświadamiać mu to i zachęcać go do tego. Zadaniem archiwów jest zatem zachęcanie i uświadamianie możliwości korzystania z archiwum, a także do tego korzystania przygotowywanie.

Archiwa w zakresie realizacji prac publicznych swoją uwagę skupiają raczej na klientach, którzy znają archiwum i korzystają z jego oferty. Przez promowanie i edukowanie, próbują wyjść z inicjatywą także do tej części społeczeństwa, potencjalnych klientów, którzy nie znają archiwów, ich misji i zasobów. 
Pojawiają się dwa problemy: wypracowanie metod współpracy i sposobów dotarcia z informacją o archiwum i jego ofercie do wszystkich klientów (czyli zarówno tych, którzy już znają archiwum, jak i tych, którzy jeszcze go nie znają), a także ich edukowanie, co to jest archiwum, jak się z niego korzysta, co przechowuje.

Aby sprostać tym wyzwaniom nadrzędnymi celami archiwów jest budowanie pozytywnego wizerunku archiwum w społeczeństwie, pokazanie, że jest to placówka profesjonalna, w której przechowywane są najważniejsze dokumenty, ale też placówka właściwa do ich przechowywania, a także edukowanie społeczeństwa, nie tylko realnych, ale też potencjalnych klientów. Przygotowania potrzebuje zarówno użytkownik, który korzysta już z zasobu, także ten, który odwiedził archiwum lub jego stronę internetową, jak i ten, który jeszcze o archiwum nie słyszał, nie zna jego roli i misji, również znaczenia przechowywanych w nim materiałów archiwalnych.

Działania podejmowane przez archiwa w zakresie realizacji publiczności archiwów, promowanie i edukowanie wymagają długofalowych, zaplanowanych prac u podstaw. Współpraca z instytucjami oświaty, uniwersytetami, grupami formalnymi i nieformalnymi, władzami lokalnymi, wytwórcami dokumentacji, instytucjami kultury, obecność w przestrzeni publicznej, prasie, radiu, telewizji, internecie, przyniesie efekty. Archiwa w Polsce dopiero od kilku lat świadomie realizują zadania wynikające z funkcji promocyjnej i edukacyjnej, doceniono już potencjał tych działań. Ich skutki dostrzegalne w szerszej skali będą dopiero w przyszłości.

$\mathrm{Na}$ koniec chcę zwrócić uwagę jeszcze na jedno poruszone w liście do redakcji zagadnienie. Różnorodność zadań i nadmierne bogactwo zasobu archiwów nie pozwala im wyeksponować go tak, jak mogłyby to uczynić muzea skoncentrowane na konkretnych wątkach i szukające zazwyczaj obiektów. Pan Robert ma zatem rację. Archiwa nie dościgną muzeów. Ich rolą jest dostarczanie obiektów wszystkim poszukującym, również muzeom.

Od Redakcji Agnieszka Rosa 